\title{
ACADEMICIAN N.A. LOGATCHEV AND HIS SCIENTIFIC SCHOOL: CONTRUBITION TO STUDIES OF THE CENOZOIC CONTINENTAL RIFTING
}

\author{
S. V. Rasskazov1, 2, S. I. Sherman ${ }^{1}$, K. G. Levi', \\ V. V. Ruzhich${ }^{1}$, V. M. Kozhevnikov' ${ }^{1}$, V. A. San'kov ${ }^{1}$ \\ ${ }^{1}$ Institute of the Earth's Crust, Siberian Branch of RAS, 664033, Irkutsk, Lermontov street, 128, Russia \\ 2Irkutsk State University, Irkutsk, Russia
}

Abstract: N.A. Florensov and N.A. Logatchev pioneered development of fundamental concepts of the structure and evolution of the Baikal system of rift basins. At the turn to the 21 st century, in view of the wide availability of scientific research data on the Cenozoic continental rift zones located in Eurasia, Africa and North America, and taking into account the application of new research methods and options to process and analyze huge amounts of geological and geophysical data, a priority was comprehensive modeling of rifting from its origin to the current period of time. This scientific challenge was addressed by the research team under the leadership of N.A. Logachev.

Keywords: the Cenozoic rift basins, the Baikal rift, volcanism, rifting, seismicity.

\section{АКАДЕМИК Н.А. ЛОГАЧЕВ И ЕГО НАУЧНАЯ ШКОЛА: ВКЛАД В ИЗУЧЕНИЕ КАЙНОЗОЙСКОГО КОНТИНЕНТАЛЬНОГО РИФТОГЕНЕЗА}

\author{
С. В. Рассказов ${ }^{1,2}$, С. И. Шерман ${ }^{1}$, К. Г. Леви ${ }^{1}$, \\ В. В. Ружич ${ }^{1}$, В. М. Кожевников ${ }^{1}$, В. А. Саньков ${ }^{1}$
}

1Институт земной коры СО РАН, 664033, Иркутск, ул. Лермонтова, 128, Россия

2Иркутский государственный университет, Иркутск, Россия

\begin{abstract}
Аннотация:. Фундаментальные представления о строении и развитии Байкальской системы рифтовых впадин были заложены в трудах Н.А. Флоренсова и Н.А. Логачева. Высокая степень изученности кайнозойских континентальных рифтовых зон Евразии, Африки и Северной Америки, а также новые методики и возможности обработки и анализа больших массивов геологической и геофизической информации выдвинули на рубеже XX и XXI столетий в качестве приоритетной задачи создание комплексной модели развития рифртогенеза с его зарождения до современности. Решение поставленной задачи осуществлялось в рамках работ научной школы под руководством Н.А. Логачева.
\end{abstract}




\section{ВведенИЕ}

Кайнозойский континентальный рифтогенез - явление планетарного масштаба. Исследования конца XX - начала XXI столетия показали сходство и различия рифтов разных континентов. Их общность заключена в процессах растяжения и утонения коры и литосферы, сопровождающихся образованием впадин на земной поверхности. Различия проявляются в ускоренном и замедленном прогибании впадин. Иногда образуются инверсионные поднятия. В рифтогенез вовлекаются территории, испытавшие орогенез и находившиеся в длительном тектоническом покое. В одних случаях рифтогенез сопровождается исключительно глубинным (мантийным) базальтовым магматизмом, в других - магматизмом разных уровней мантии и коры - от базальтового до андезитового и риолитового. Некоторые структуры растяжения, считающиеся рифтовыми, не имеют вулканического сопровождения.

Хотя в перечень рифтов кайнозоя включены многочисленные структуры различных континентов [Шенгёр, Натальин, 2009], классическим воплощением рифтогенеза этой эпохи служат системы впадин Восточной Африки и Центральной Азии. Существенный вклад в изучение обеих территорий с заложением основ теории рифтогенеза был сделан Н.А. Логачевым, стоявшим у истоков современных знаний об этом геологическом феномене.

\section{РАЗВИТИЕ БАЗОВЫХ ИССЛЕДОВАНИЙ СИСТЕМЫ БАЙКАЛЬСКИХ ВПАДИН: ОБЪЕКТИВНЫЕ УСЛОВИЯ СОЗДАНИЯ НАУЧНОЙ ШКОЛЫ}

Впадина оз. Байкал давно привлекала внимание исследователей Сибири. Уже в 1772 г. П.С. Паллас, наблюдая «утесы конгломератов на западном берегу озера, пришел к убеждению, что котловина Байкала представляет собой громадную трещину, разделившую горы и заполнившуюся водой», а позднее, в 1871-1874 гг., А.Л. Чекановский излагал «взгляд на происхождение впадины Байкала как громадной трещины в юрской формации» [Флоренсов, 1960, с. 5 и 8]. На этом основании можно утверждать, что термин «трещина» был применен на русском языке для обозначения структуры растяжения оз. Байкал на 122 года раньше, чем для обозначения на английском языке сброса, возникшего под влиянием гравитационных сил и ограничивающего рифтовую долину в Восточной Африке [Gregory, 1894].

В книге «Мезозойские и кайнозойские впадины Прибайкалья», опубликованной в 1960 г., Н.А. Флоренсов провел первичный анализ исходных данных и дал подробный обзор имевшихся материалов и выводов исследователей Прибайкалья, обратив особое внимание на то, что впадины байкальского типа сравнивались с впадинами Восточной Африки и Аравии А.В. Львовым (1904 г.) и Е.В. Павловским (1930-е гг.). Рассматривая распределение вулканогенных и осадочных формаций в рельефе, он при- шел к выводу «об исключительной локализации кайнозойских впадин в Прибайкалье, о том, что последние как бы вложены, «втиснуты» в гораздо более широкое и ровное мезозойское тектоническое поле» [Флоренсов, 1960, с. 189].

Характеристика осадочных и вулканических пород Тункинской впадины и Еловского отрога - одной из ключевых территорий Байкальской рифтовой зоны (БРЗ) - приведена в монографии Н.А. Флоренсова в основном по материалам, полученным и опубликованным Н.А. Логачевым в 1955-1958 гг. Эта книга «явилась не только крупным событием восточно-сибирского масштаба, но и предтечей многих региональных и надрегиональных работ как самого Николая Александровича, так и его учеников и последователей» [Николай Александрович Флоренсов, 2003, с. 21]. В монографиии «Нагорья Прибайкалья и Забайкалья» (1974г.), подготовленной коллективом авторов под научным руководством Н.А. Логачева, понимание последовательности и условий формирования кайнозойских отложений во впадинах БРЗ и сопредельных территорий было поднято уже на новый уровень благодаря созданию в конце 50-х и первой половине 60-х годов региональных стратиграфических схем. Эта книга опубликована в составе многотомной монографической серии «История развития рельефа Сибири и Дальнего Востока» (1960-1976 гг.), отмеченной Государственной премией СССР в области науки и техники. Авторский коллектив многотомной серии «Геология и сейсмичность зоны БАМ» (1983-1984 гг.), изданной под редакцией Н.А. Логачева, был удостоен премии Совета Министров СССР в области науки и техники.

Результаты работ по Байкальскому рифту выведены на международный уровень, прежде всего, благодаря активности Н.А. Логачева. На базе Института земной коры СО АН СССР (в настоящее время - ИЗК СО РАН) в июне 1966 г. состоялась выездная сессия Научного совета по комплексным исследованиям земной коры и верхней мантии с геологической экскурсией по Байкалу и в Тункинскую впадину и была принята программа исследований Байкальской рифтовой зоны по проекту «Верхняя мантия». Общее руководство проектом осуществлял член-корреспондент АН СССР В.В. Белоусов, предложивший включить Н.А. в состав экспедиции АН СССР по изучению Восточно-Африканской рифтовой системы (1967-1969 гг.) [Белоусов и дp., 1974a, б, в]. Позже он вошел в состав Рабочей группы № 4 по международному геодинамическому проекту «Континентальные и океанические рифты», проводил исследования по Геодинамическому проекту и программе «Литосфера», выступал в качестве руководителя с российской стороны в совместных советско-американских сравнительных исследованиях рифтов Байкала и Рио-Гранде (1988-1989 гг.) и в совместных российско-европейских исследованиях Байкальской и Восточно-Африканской рифтовых систем по проектам ИНТАС «Сравнительный анализ механизмов осадконакопления в рифтах» (CASIMIR) и «Тектоника континентальных рифтов и 


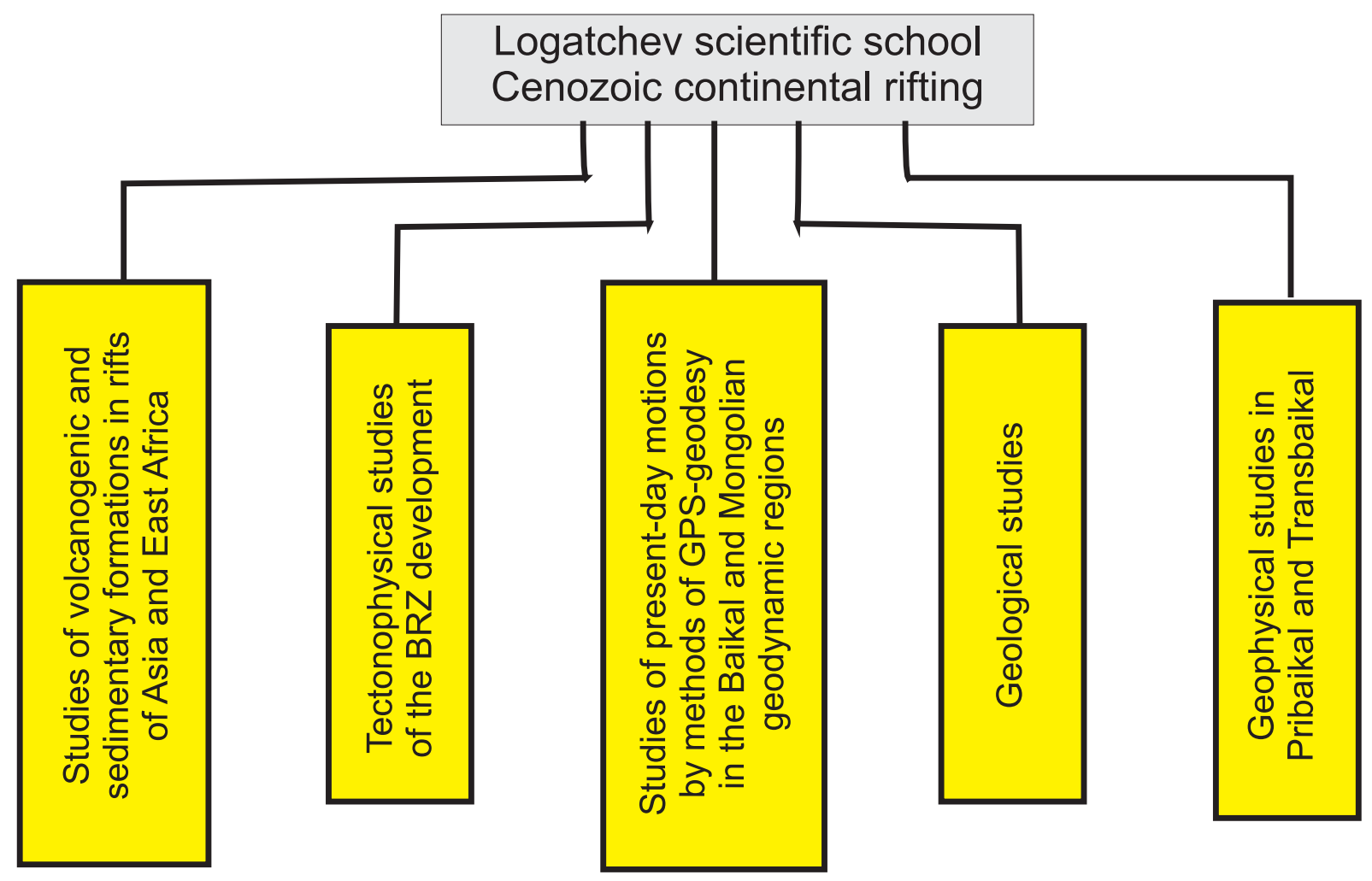

Рис. 1. Направления научной школы Н.А. Логачева «Кайнозойский континентальный рифтогенез».

Fig. 1. Scientific directions in the Logatchev school for studies of the Cenozoic continental rifting.

эволюция осадочных бассейнов» (1990-1996 гг.).

Основные положения проекта CASIMIR были доложены в г. Новосибирске на специализированном совещании под эгидой НАTO [Klerkx et al., 1995]. В рамках проекта при ИЗК СО РАН был создан научно-исследовательский Центр по изучению активной тектоники, велись международные комплексные геолого-геофизические исследования рифтов Сибири и Африки, осуществлялись международные экспедиции, публиковались материалы этих исследований в международной печати. В Центре было осуществлено издание специальных выпусков журнала «Bulletin Centre of Researches of Elf Explorer Production», в которых были изложены материалы комплексных геолого-геофизических исследований Восточно-Африканской и Байкальской рифртовых систем [Logatchev, 1993; Rasskazov, 1994; Kashik, Mazilov, 1994; и дp.]. Научные исследования по рифртовой тематике в рамках проекта CASIMIR оказались в конечном итоге одним из важнейших событий для ИЗК СО РАН и его директора академика H.A. Логачева. Начавшиеся чуть позже GPS-геодинамические исследования на Монголо-Байкальском полигоне, по существу, зародились в недрах этого проекта.

Высокая степень изученности кайнозойских континентальных рифртовых зон Евразии, Африки и Северной Америки, а также новые методики и возможности обработки и анализа больших массивов геологической и геофизической информации выдвину- ли на рубеже XX и XXI столетий в качестве приоритетной задачи создание комплексной модели развития рифртогенеза с его зарождения до современности. Для обоснования модели осуществлялся литолого-фрациальный и формационный анализ осадочного и вулканогенного наполнения рифртовых впадин, изучались микроэлементные и изотопные характеристики магматических пород, генетически или парагенетически связанных с рифтогенезом, выявлялись особенности напряженного состояния литосферы, сочетающего растяжение со сдвигом, определялся уровень современной тектонической активности, выражаемой сейсмичностью и юным разломообразованием, проводилась комплексная обработка геофизических и петрологических данных о строении, состоянии и возможном составе глубинных частей литосферы и астеносферы. Выяснялись условия развития рифтогенеза во внутренних частях и на окраинах материков, определялась потенциальная способность мощных осадочных толщ рифтовых впадин к продуцированию и накоплению энергоносителей (нефть, газ, бурый уголь) и природа различий рифртовых зон по уровню сейсмотектонической активности и тенденциям в развитии опасных экзогеодинамических процессов. Решение поставленных задач в рамках работ научной школы «Кайнозойский континентальный рифтогенез» (РФФИ 00-15-98574) осуществлялось под руководством Н.А. Логачева по пяти направлениям (рис. 1). 


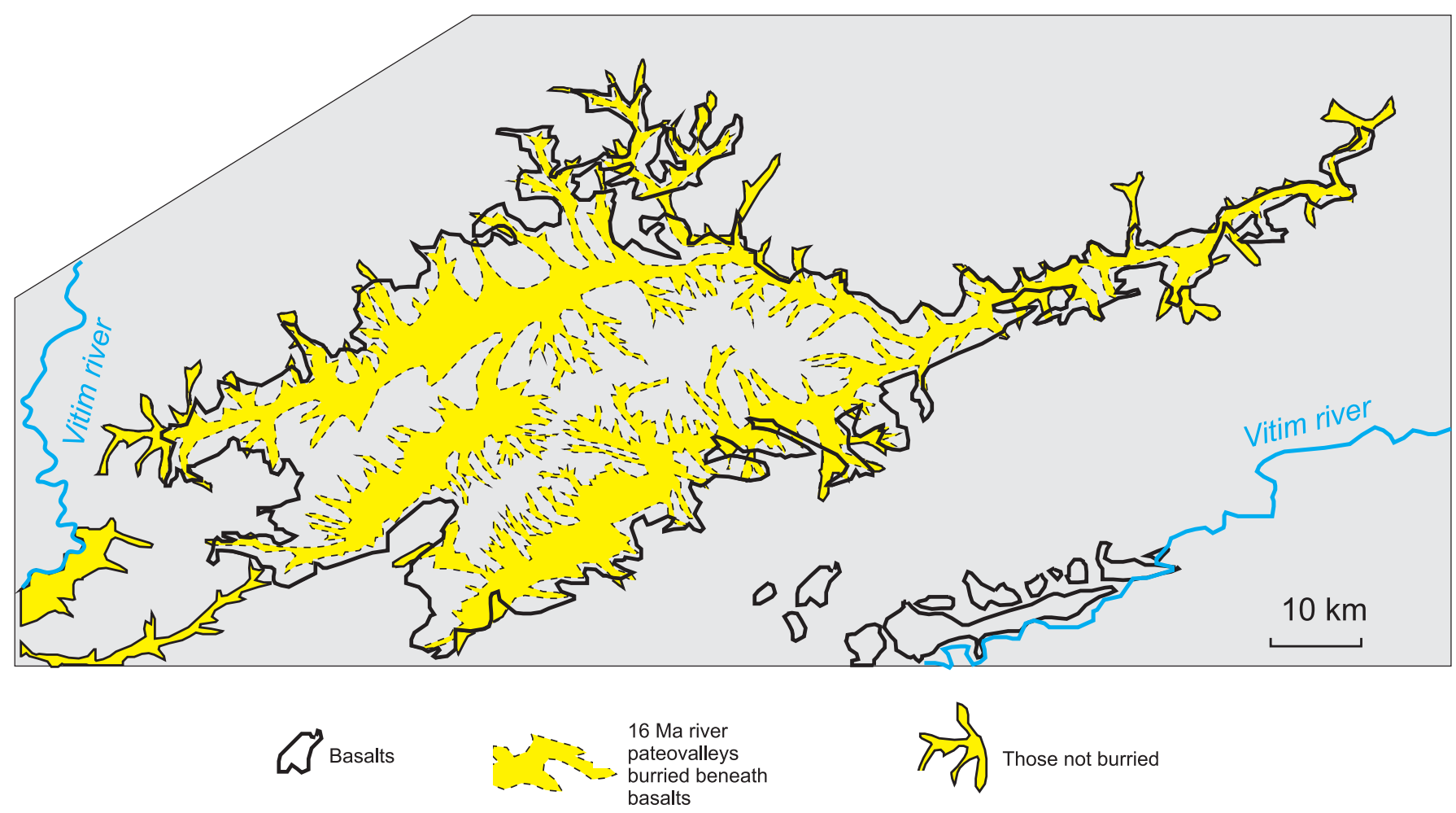

Рис. 2. Раннемиоценовые палеодолины, погребенные под лавами Витимского вулканического поля [Рассказов и др., 2001].

Fig. 2. Early Miocene river paleovalleys buried beneath lavas of the Vitim volcanic field [Рассказов и др., 2001].

\section{ИЗУЧЕНИЕ ВУЛКАНОГЕННЫХ И ОСАДОЧНЫХ ФОРМАЦИЙ В РИФТАХ АЗИИ И ВОСТОЧНОЙ АФРИКИ}

Смена мелкообломочных осадочных отложений грубообломочными молассоидами в разрезах осадочного наполнения рифтовых впадин интерпретировалась как свидетельство двух этапов их прогибания - медленного и быстрого [Logatchev, Florensov, 1978]. На основе общего анализа геофизических данных и структуры Байкальской рифтовой зоны предполагалось постепенное поднятие границы астеносфреры-литосферы от 120-150 км до современного уровня 40-50 км под осевой частью Саяно-Байкальского свода начиная приблизительно с 30 млн лет назад [Logatchev et al., 1983; Logatchev, Zorin, 1987, 1992; Logatchev, 1993].

В монографиях «Магматизм Байкальской рифтовой системы» [Рассказов, 1993] и «Геохронология и геодинамика позднего кайнозоя: Южная Сибирь Южная и Восточная Азия» [Рассказов и др., 2000], а также в серии статей [Логачев и др., 1998; Рассказов и др., 1998, 2001; и др.] приведены результаты систематического радиоизотопного датирования вулканических и вулканогенно-осадочных толщ позднего кайнозоя юга Сибири (Восточный Саян, Витимское плоскогорье, хр. Удокан) и сравнительных реконструкций вулканизма с привлечением геохронологических данных по другим территориям Азии. Был получен вывод о значительном (не менее 500 м) расчленении рельефа Тункинской рифтовой долины и Витимского плоскогорья на рубеже ранне- го и среднего миоцена. На последней территории по данным бурения скважин установлена развитая речная сеть этого возраста (рис. 2). По измеренным соотношениям радиоактивного ${ }^{40} \mathrm{~K}$ и радиогенного ${ }^{40} \mathrm{Ar}$, накапливавшегося в открытой и закрытой системе вермикулита, палеоценовая кора выветривания была впервые датирована возрастом $59 \pm 5$ млн лет [Логачев и др., 2002].

Важные заключения были сделаны при сравнительном изучении вулканогенных и осадочных формаций рифтов Азии и Восточной Африки. Для последнего региона была разработана новая схема пространственно-временной эволюции вулканизма и рифтогенеза с определением характера зарождения и распространения подлитосферной термальной аномалии. Ее основу составили выявленные прежде закономерности распределения вулканогенных и осадочных фрормаций [Белоусов и др., 1974а, б, в; Логачев, 1977; Милановский, 1976] и новые результаты ${ }^{40} \mathrm{Ar}-{ }^{39} \mathrm{Ar}$ датирования вулканических пород поля Рунгве Западного рифта, полученные по проекту CASIMIR. Установлено, что глубинный разогрев начинался в среднем эоцене в районе Турканской седловины, разделяющей Эфиопское и Восточно-Африканское плато. Мощное плюмовое термальное воздействие на литосферу первого плато выразилось в массовых вулканических извержениях, распространившихся в его центральной части вдоль Эфиопского рифта 30 млн лет назад. На втором плато термальная эрозия литосферы была рассредоточена под периферией - в Кений- 


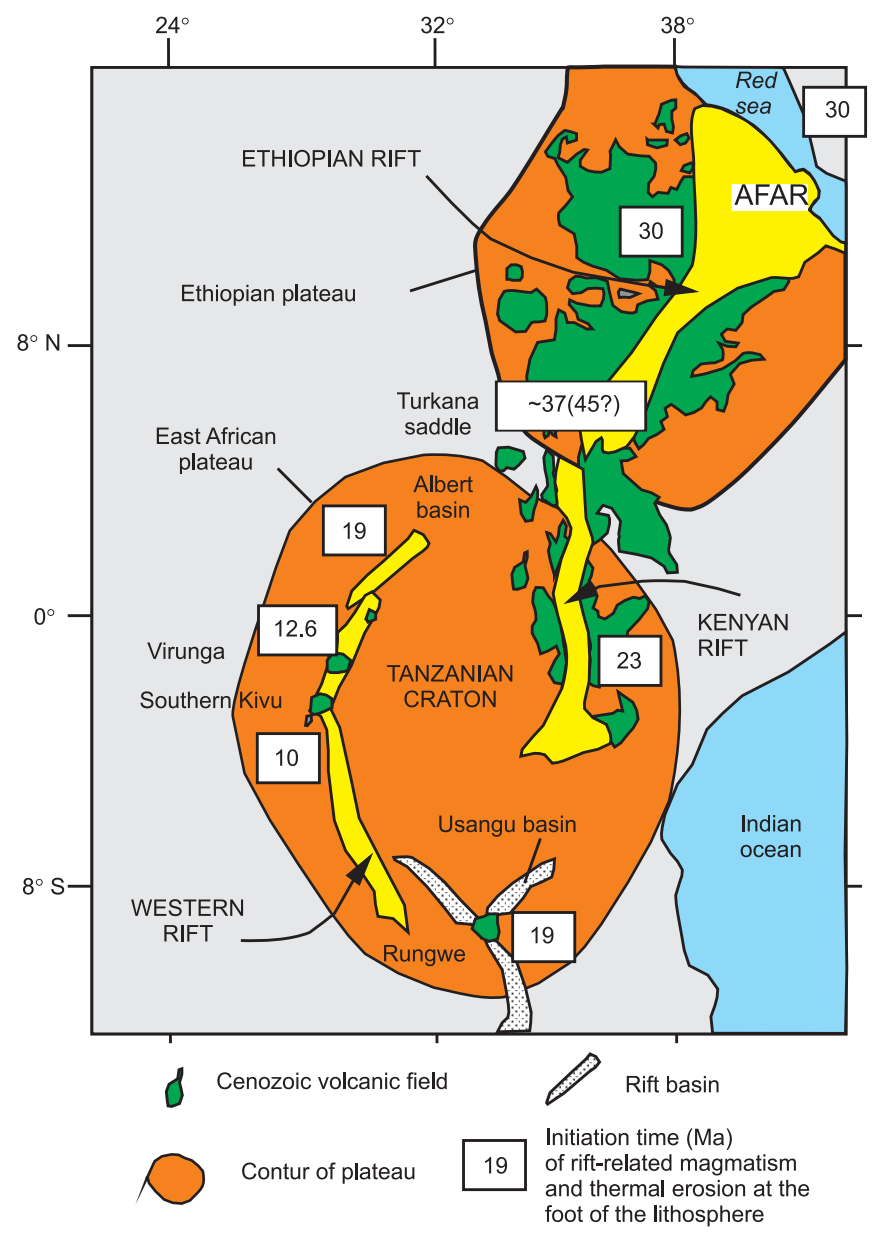

Рис. 3. Пространственно-временное распространение магматизма и термальной эрозии подошвы литосферы в Восточной Африке [Рассказов и др., 2003б]. Для впадины Альберт показано время начала осадконакопления.

Fig. 3. Spatial-temporal propagation of magmatism and thermal erosion of the lithosphere in Northeast Africa [Рассказов и др., 20036]. For the Albert basin, the initial time of sedimentation is shown.

ском рифте начиная с 23 млн лет назад, а в Западном рифте - с 19 млн лет назад (рис. 3). В Байкальской рифтовой системе имело место подобное асинхронное двустороннее распространение вулканизма и рифтогенеза от Селенгинской седловины, разделяющей Саяно-Хамардабанское и Становое поднятия [Логачев, 2003; Рассказов и др., 2003б].

\section{ГЕОЛОГИЧЕСКИЕ ИССЛЕДОВАНИЯ}

Вслед за своим учителем Н.А. Флоренсовым, Н.А. Логачев придавал громадное значение исследованиям разломной тектоники, а в ряде исследований принимал активное участие как руководитель и исполнитель работ, результаты которых имеют и сегодня принципиальное отношение к организованной им научной школе.

Геологические исследования были ориентированы на выяснение природы развития в пределах Байкальской рифтовой зоны, наряду со сбросами, разломов взбросо-надвигового типа, порожденных тангенциальным сжатием земной коры в направлении северо-восток - юго-запад [Ружич и др., 1972; Ружич, 1975]. По результатам многолетнего изучения режимов неотектонических и современных (установленных инструментальными методами) движений в зонах разломов рифтовой зоны сделан вывод о том, что парагенезис сбросов и взбросов обусловлен регулярным проявлением в рифтогенный этап чередования периодов сжатия в направлении северо-восток - юго-запад и растяжения в направлении северо-запад - юго-восток, инициируемых квазирегулярными колебательно-волновыми деформациями массивов горных пород. Природа последних разнообразна и обусловлена воздействием комплекса фракторов - твердоприливными суточными деформациями, а также параметрами ротационного режима Земли, гравитационным и электромагнитным взаимодействием системы Солнце-ЛунаЗемля, отражающимся в наблюдаемой квазипериодичности сейсмической активности [Ружич, 1978].

К началу 1970-х годов впадины БРЗ были изучены достаточно детально, а разломная тектоника и междувпадинные перемычки - несколько слабее. Детальные работы, проведенные в юго-западной части БРЗ [Шерман и др., 1973], а затем и по всей ее территории [Шерман, 1977], показали, что ее главные разломы являются структурами сложного докайнозойского развития, предопределившего и стимулирующего развитие впадин на всех предшествовавших (по крайней мере, с мезозоя) возрастных этапах. Формирование глубинных и генеральных разломов под углом зрения механики разрушения представляет собой квазипластическое течение вещества горных пород, состоящее из серии медленных и быстрых подвижек в верхних горизонтах коры и пластического движения вещества - в более глубоких. Впервые был сделан вывод о том, что образование сетки разломов в земной коре происходит по законам разрушения упруговязкого тела Максвелла [Шерман, 1977]. Докайнозойской структурой фундамента предопределена S-образная форма БР3 (рис. 4). Структура рифртогенных впадин и перемычек во многом обусловлена унаследованными деформациями в зонах разломов дорифтогенного тектонического развития земной коры [Pyжич, 1975; Zamarayev, Ruzhich, 1978]. Активизация разломов в период рифтогенеза приобрела характерные кинематические закономерности, подчиненные полю кайнозойских напряжений - растяжению в центральной части и сдвиговым полям - на флангах. Установлено, что все основные разломы Байкальской рифтовой зоны приобрели сдвиговую компоненту. При этом направление сдвига изменяется в зависимости от ориентировки разлома: разломы широтной ориентировки имеют, как правило, левостороннюю сдвиговую компоненту, разломы северовосточного (до СВ 60) простирания - правостороннюю, разломы с простиранием около СВ $60^{\circ}-$ типичные нормальные сбросы [Шерман и др., 1992]. При большой научной и моральной поддержке Н.А. Логачева впервые была проведена квантификация разломов БРЗ и на этой концептуальной основе вы- 


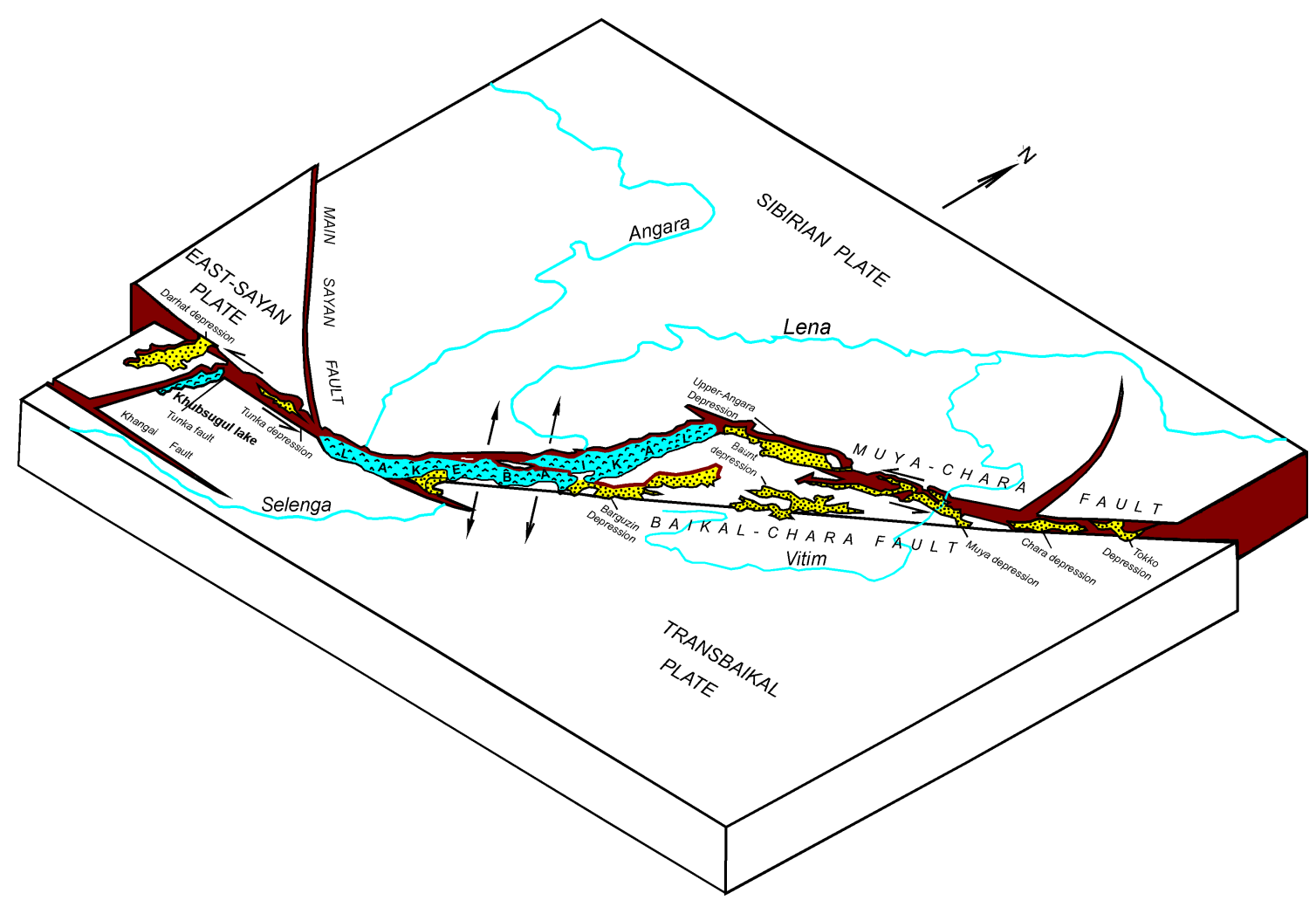

Рис. 4. Блок-диаграмма Байкальской рифтовой зоны [Шерман, Леви, 1977].

Fig. 4. Block-diagram of the Baikal rift zone [Шерман, Леви, 1977].

полнен комплекс исследований по разломообразованию в литосфере [Шерман и др., 1991, 1992, 1994].

В последние два десятилетия более углубленно рассмотрен ряд вопросов, связанных с изучением признаков и механизмов взаимодействия процессов рифртогенеза в Прибайкалье с Индо-Евразийским коллизионным процессом [Logatchev et al., 1996; Ружич, 1997; Рассказов и др., 1998; Логачев, 2003; Calais et al., 2003; Rasskazov et al., 2010; u dp.]. B результате новых подходов получены важные сведения, касающиеся выявления и изучения признаков подобного геодинамического взаимодействия с позиций физического моделирования на ледяном покрове оз. Байкал [Ружич и др., 2009]. Для высокоточных измерений режима современных смещений в зонах разломов был сконструирован измерительный комплекс «Сдвиг». Его применение позволило получить уникальную информацию о весьма сложном современном режиме деформаций сжатия и растяжения в зонах разломов Прибайкалья и изучить механизмы инициации этих движений [Ружич и др., 1999].

Независимо от предшествовавшей истории развития, в кайнозое фиксируется закономерная перестройка всех главных разломов БРЗ: они превращаются в сдвиго-сбросы. Установлено, что направление сдвига коррелирует с простиранием разломов: все субширотные разломы имеют левостороннюю сдвиговую компоненту, субмеридиональные и северо-восточные - правостороннюю. Эта закономерность объяснена кинематикой раздвижения коры при формировании и активном развитии БРЗ над областью разуплотнения аномальной мантии.

В течение 1997-2001 гг. под руководством Н.А. Логачева выполнялся один из первых в Сибирском отделении РАН интеграционных проектов «Трехмерная геодинамическая модель Центральной Азии В кайнозое». В работе по проекту принимали участие сотрудники ИЗК СО РАН, ОИГГИМ СО РАН и других научных и производственных организаций. Результаты работы изложены в монографии «Актуальные вопросы современной геодинамики Центральной Азии», вышедшей в 2005 г., после смерти Н.А. Логачева. В этой книге комплексированы результаты геолого-геофизических исследований континентального рифтогенеза всей континентальной Азии.

\section{ТЕКТОНОФИЗИЧЕСКИЕ ИССЛЕДОВАНИЯ УСЛОВИЙ ФОРМИРОВАНИЯ БАЙКАЛЬСКОЙ РИФТОВОЙ ЗОНЫ}

Постановка исследований разломообразования как процесса деструкции литосфреры послужила основанием для создания в 1977 г. впервые в СО РАН лаборатории тектонофизики. В лаборатории с активным участием Н.А. Логачева проводилось физическое моделирование образования БРЗ [Логачев и др., 2000]. Установлено, что гетерогенная природа БР3 обусловила наличие в ее строении широкого 


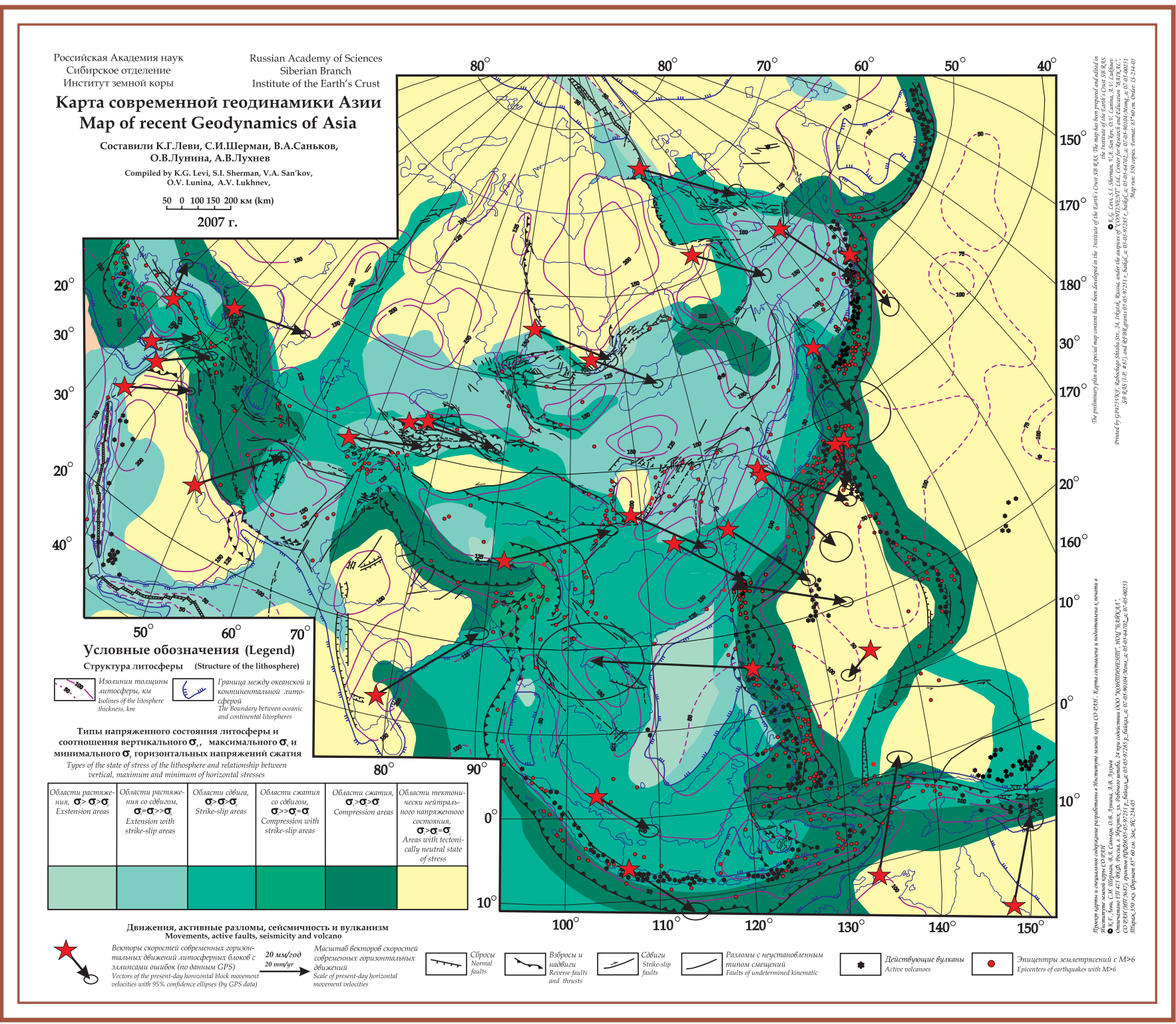

Рис. 5. Карта современной геодинамики Азии [Карта..., 2007].

Fig. 5. Map of recent geodynamics of Asia [Kapma..., 2007].

спектра структурных элементов, свойственных как пассивным, так и активным рифтам, что, в конечном счете, не позволило однозначно типизировать ее по механизму образования.

Для физических экспериментов использовались глинистые пасты с полным соблюдением условий подобия. Процессы пассивного и активного рифтогенеза моделировались при разных условиях нагружения в соответствии со схемами, при которых источниками сил были подлитосферное нагружение и/или боковое сжатие, имитирующее Индо-Азиатскую коллизию. Результаты проведенного экспериментального исследования позволили говорить, что при фрормировании БРЗ ведущие источники региональных напряжений - подлитосферные и коллизионные - чередовались. Таким образом, в результате физического моделирования два конкурировав- ших взгляда на механизм кайнозойского внутриконтинентального рифтогенеза в Центральной Азии сошлись на признании взаимодействия местных и удаленных силовых источников - совместного действия «активного» и «пассивного» механизмов растяжения. Результаты исследований лаборатории по разноранговым разломным структурам были обобщены в трехтомной монографии «Разломообразование в литосфере», изданной под редакцией Н.А. Логачева [Шерман и др., 1991, 1992, 1994].

Большое внимание уделялось Н.А. Логачевым изучению геодинамики БРЗ и континентальной литосферы в целом. В работах [Логачев и др., 1987a, б, 1991] впервые сорормулировано понятие о геодинамической активности литосферы. Литосфера это комплексное структурное представление о верхней оболочке Земли. Активность литосферы выра- 


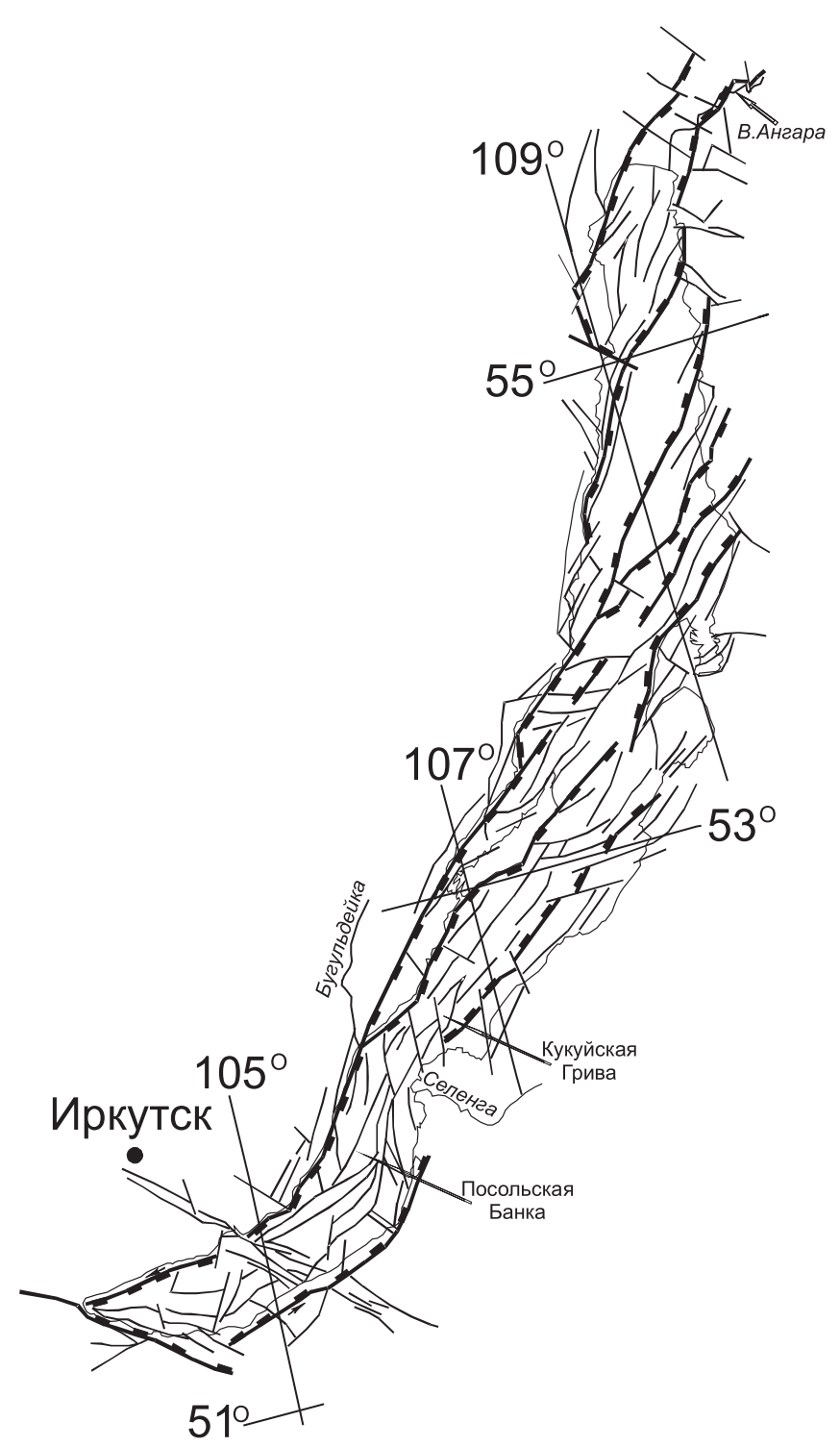

Рис. 6. Активные разломы Байкальской впадины [Леви и др., 1995; Levi et al., 1997].

Fig. 6. Active faults of the Baikal basin [Леви и др., 1995; Levi et al., 1997].

жается в согласованном воздействии на нее сложной многокомпонентной системы частных эндогенных процессов, приводящих к последовательному преобразованию ее внутренней структуры. Последнюю определяет группа геотектонических факторов: скоростей и амплитуд движений, градиентов скоростей движений, интенсивности развития геологических структур определенного возраста, тепловых потоков и магматизма, а также сейсмичности, толщины литосферы и других компонентов, в целом выражающих мощность их энергетических источников. По этим признакам можно картировать масштабы и степень выраженности на земной поверхности геодинамической активности литосферы.

Были составлены и опубликованы «Схема геодинамической активности литосферы Азии» [Лога- чев и др., 1991], «Схема геодинамической активности литосферы Сибири» [Логачев и др., 1987а, б], на первичной идеологии которых с существенными добавлениями составлена «Карта современной геодинамики Азии» (рис. 5). На ней впервые в базовую основу положены три определяющих современную геодинамику параметра: толщина литосферы, напряженное состояние и векторы современных движений ее верхней хрупкой части. В качестве других факторов современной геодинамики показаны активные разломы и вулканы, эпицентры землетрясений с $\mathrm{M} \geq 6.0$. Реализованная на «Карте современной геодинамики Азии» модель является фундаментальной базой для пространственно-временного анализа современных геолого-геофизических процессов эндогенного происхождения.

B рамках проекта CASIMIR на базе морских геофизических и геолого-структурных исследований на берегах оз. Байкал впервые была составлена карта активных разломов Байкальской впадины [Леви u др., 1995; Levi et al., 1997] (рис. 6). Впервые обосновано современное структурно-тектоническое районирование впадины оз. Байкал, выявлены ее главные структурные элементы, рассмотрены аспекты гляциоизостазии в Байкальском рифте, выполнены вычисления квазивязкости литосферы в Байкальской рифтовой зоне.

Тектонофизическое направление научной школы Н.А. Логачева продолжает развиваться и сегодня. Здесь уместно привести цитату из его послесловия как ответственного редактора уже упомянутых монографий «Разломообразование в литосфере»: «Возникает общая проблема изучения причин избирательной активизации разломов по отношению к определенным типам геологических структур и процессов в конкретное геологическое время» [Шерман и др., 1994, с. 246]. Потребовались многие годы, чтобы эта направленность школы Н.А. Логачева приблизилась к одному из своих логических завершений - созданию тектонофизической модели Байкальской сейсмической зоны, основанной на концепции избирательной активизации структур при рифтогенезе [Шерман, 2009].

\section{ИЗУЧЕНИЕ СОВРЕМЕННЫХ ДВИЖЕНИЙ МЕТОДАМИ GPS- ГЕОДЕЗИИ НА БАЙКАЛЬСКОМ И МОНГОЛЬСКОМ ГЕОДИНАМИЧЕСКИХ ПОЛИГОНАХ}

При активном содействии Н.А. Логачева в 1994 г. в рамках российско-французского, а затем трехстороннего российско-французско-монгольского проектов были организованы исследования современных движений методом GPS-геодезии на Байкальском, Монгольском и Тувинском геодинамических полигонах. По результатам измерений впервые рассчитано поле скоростей современных движений для территории Монголо-Сибирского региона. Выявлены главные тренды горизонтальных смещений пунктов геодезической сети относительно стабильной Северной Евразии (рис. 7). Показано, что постепенное уменьшение скорости горизонтальных смещений с юго-запада по направлению к краю Сибирской платформы фриксирует активно протекающие сегодня 


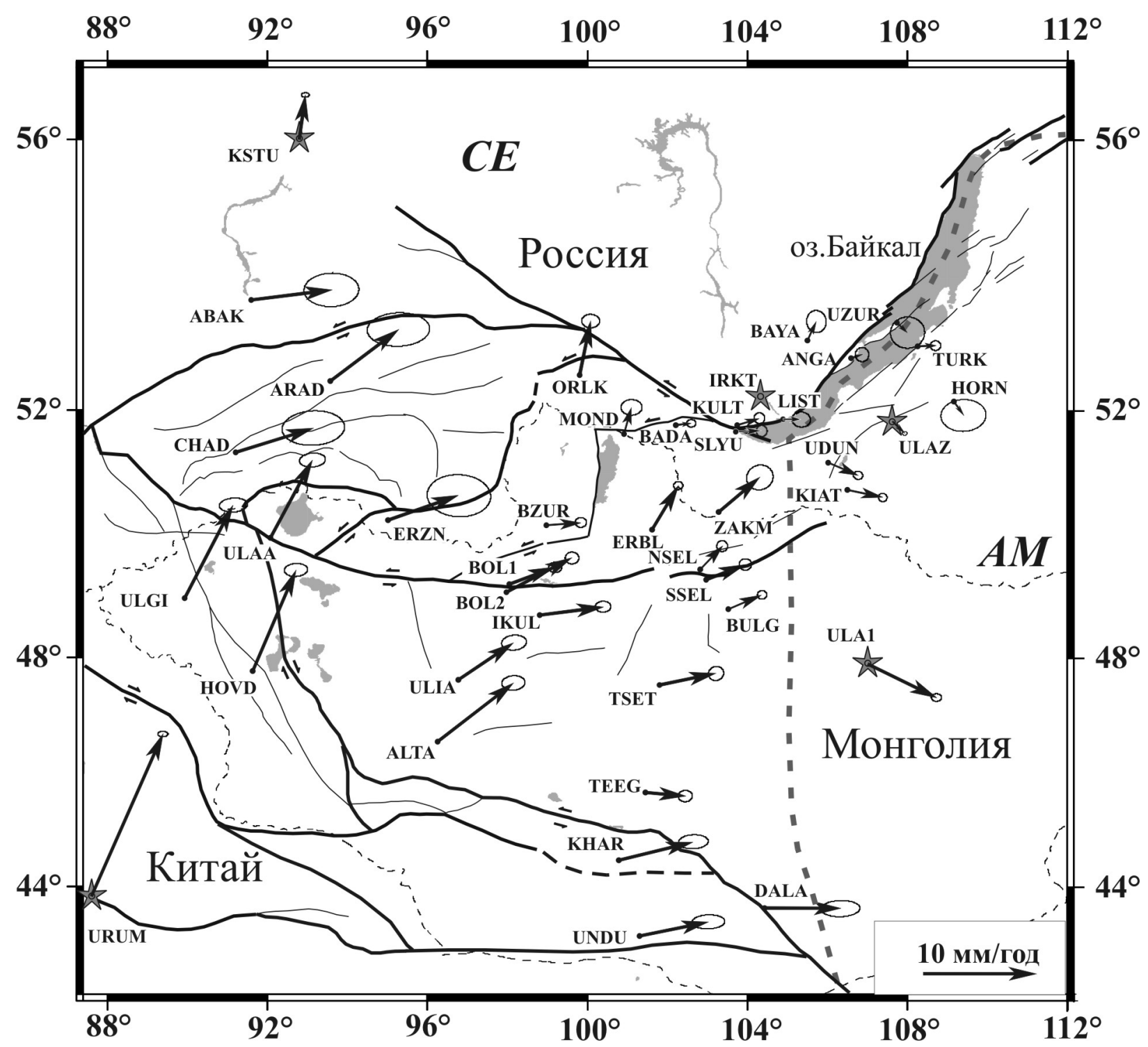

Рис. 7. Поле скоростей современных горизонтальных движений Монголо-Сибирского региона по данным измерений на Байкальском, Монгольском и Тувинском GPS-полигонах за 1994-2002 гг. Векторы скорости смещений пунктов относительно пункта IRKT (г. Иркутск) показаны с эллипсами 95\%-ного доверительного интервала. Рядом с пунктами наблюдений указаны четырехбуквенные аббревиатуры их названий и значения скорости движений в мм/год. Сплошными линиями показаны межблоковые разломы, тонкими линиями - внутриблоковые разломы, жирной пунктирной линией - граница Амурской плиты (АМ). Стрелками возле линий разломов показан знак сдвигового смещения. СЕ - стабильная Северная Евразия, АМ - Амурская плита [Саньков и др., 2003$].$

Fig. 7. The field of recent horizontal movement velocities of the Mongolia-Siberian region, according to measurement data on the Baikal, Mongolia and Tuva GPS testing areas for 1994-2002. Velocity vectors of sites relative to IRKT (Irkutsk) are shown with ellipses of the 95 percent confidence. At the measurement sites, name abbreviations and velocity rates (mm/year) are given. Inter- and intra-block faults are shown by solid thick lines and solid thin lines, respectively. The Amur plate boundary is shown by the dashed thick line. Types of horizontal displacements along strike-slip faults are shown by arrows. CE - stable North Eurasia, AM - the Amur plate [Саньков и др., 2003].

процессы сжатия земной коры в Западной Монголии и Алтае-Саянской горной области, сопровождающиеся разломообразованием и сейсмичностью. При этом в Байкальском рифте преобладают современные процессы растяжения земной коры с относительно невысокими скоростями деформаций. В целом поле векторов горизонтальных движений отражает сочетание в пределах региона перемещения континентальных масс в северо-восточном направлении под воздействием сжатия из зоны ИндоЕвразийской коллизии с выжиманием блоков за- падной части Монголии на восток, с одной стороны, и удаления Амурской плиты в юго-восточном направлении от стабильной Северной Евразии - с другой [Саньков и др., 2003].

На базе данных GPS-измерений впервые рассчитано поле современных горизонтальных деформаций для территории Южного Прибайкалья и Северной Монголии (рис. 8). Показано, что пространственное распределение преобладающих типов горизонтальных деформаций коры отвечает зональной смене условий растяжения, сдвига и сжа- 


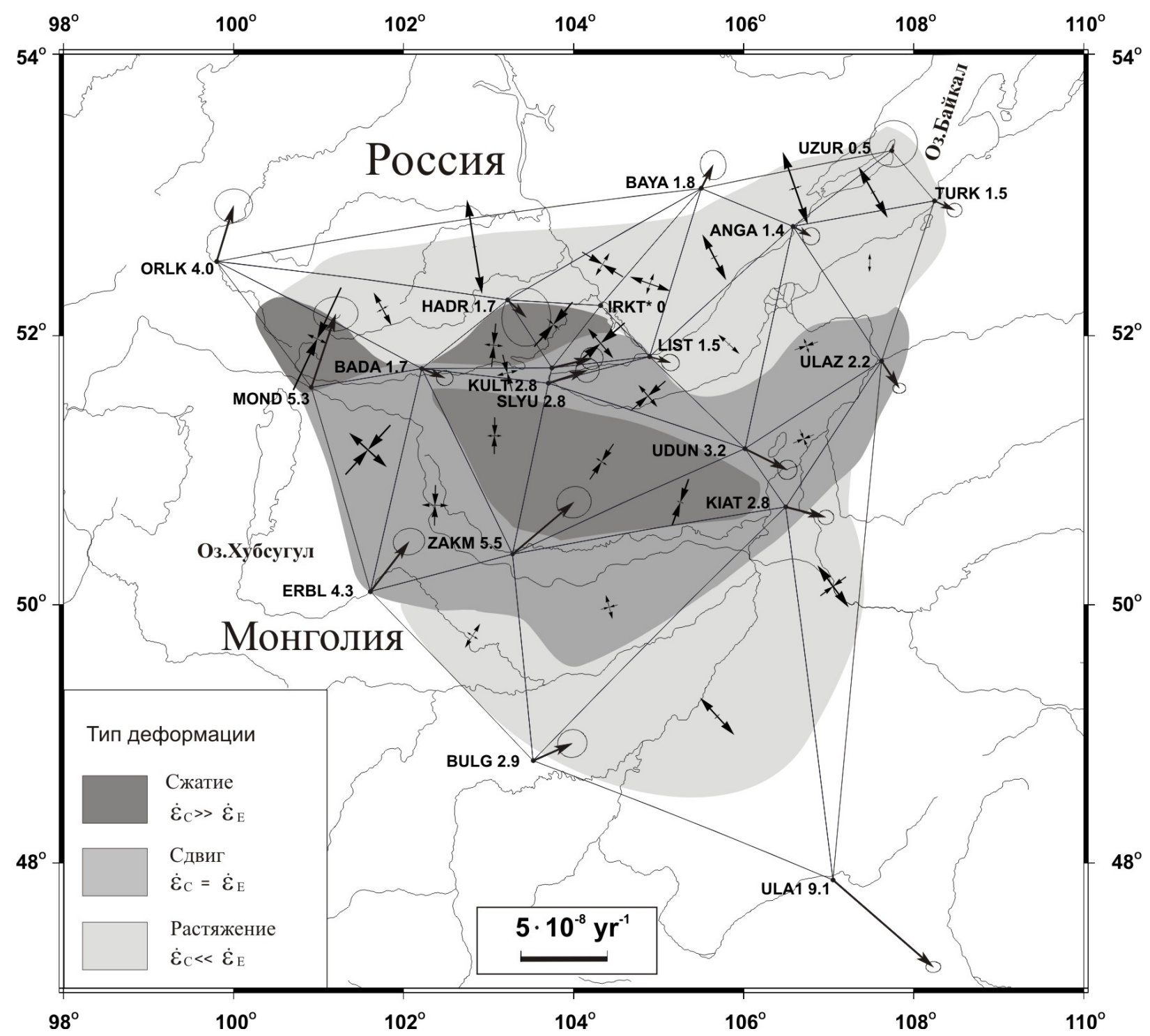

Рис. 8. Поле скоростей современных горизонтальных движений и деформаций южного обрамления Сибирской платформы по данным измерений на Байкальском и Монгольском GPS-полигонах за 1994-2001 гг. Векторы скорости смещений пунктов относительно IRKT показаны с эллипсами 95\%-ного доверительного интервала. Рядом с пунктами наблюдений указаны аббревиатуры их названий и значения скорости движений в мм/год [Лухнев и др., 2003].

Fig. 8. The field of recent horizontal movement velocities and deformation rates of the southern surroundings of the Siberian platform, according to measurement data on the Baikal and Mongolia GPS testing areas for 1994-2001. Velocity vectors of sites relative to IRKT (Irkutsk) are shown with ellipses of the 95 percent confidence. At the measurement sites, name abbreviations and velocity rates (mm/year) are given [ $/ y x-$ нев и др., 2003].

тия в направлении северо-запад - юго-восток. Впадины и понижения в региональном рельефе соответствуют областям растяжения и сдвига. Области преобладающего укорочения земной коры пространственно тяготеют к поднятиям. Тип деформаций коррелирует с типом напряженного состояния земной коры по сейсмологическим данным [Лухнев u дp., 2003].

\section{ИССЛЕДОВАНИЯ ПО НЕОТЕКТОНИКЕ И СОВРЕМЕННОЙ ГЕОДИНАМИКЕ ЦЕНТРАЛЬНОЙ АЗИИ}

Опубликована «Карта неотектоники северо-восточного сектора Евразии» в масштабе 1:7500000
[Леви, 2008], работа над которой началась еще во второй половине 1970-х годов в рамках программы по созданию комплекта тектонических карт на различные геотектонические эпохи для территории, подотчетной СО АН СССР. В 2009 г. К.Г. Леви завершен анализ основных геофизических параметров базальтового вулканизма в Байкальской рифтовой зоне, начатый еще в конце 80-х годов прошлого века. Показано, что вулканический процесс проявляется в строго ограниченных условиях напряженно-деформированного состояния земной коры и интенсивности разломообразования, что парагенетическая связь вулканического процесса с рифтогенезом является кажущейся из-за макси- 


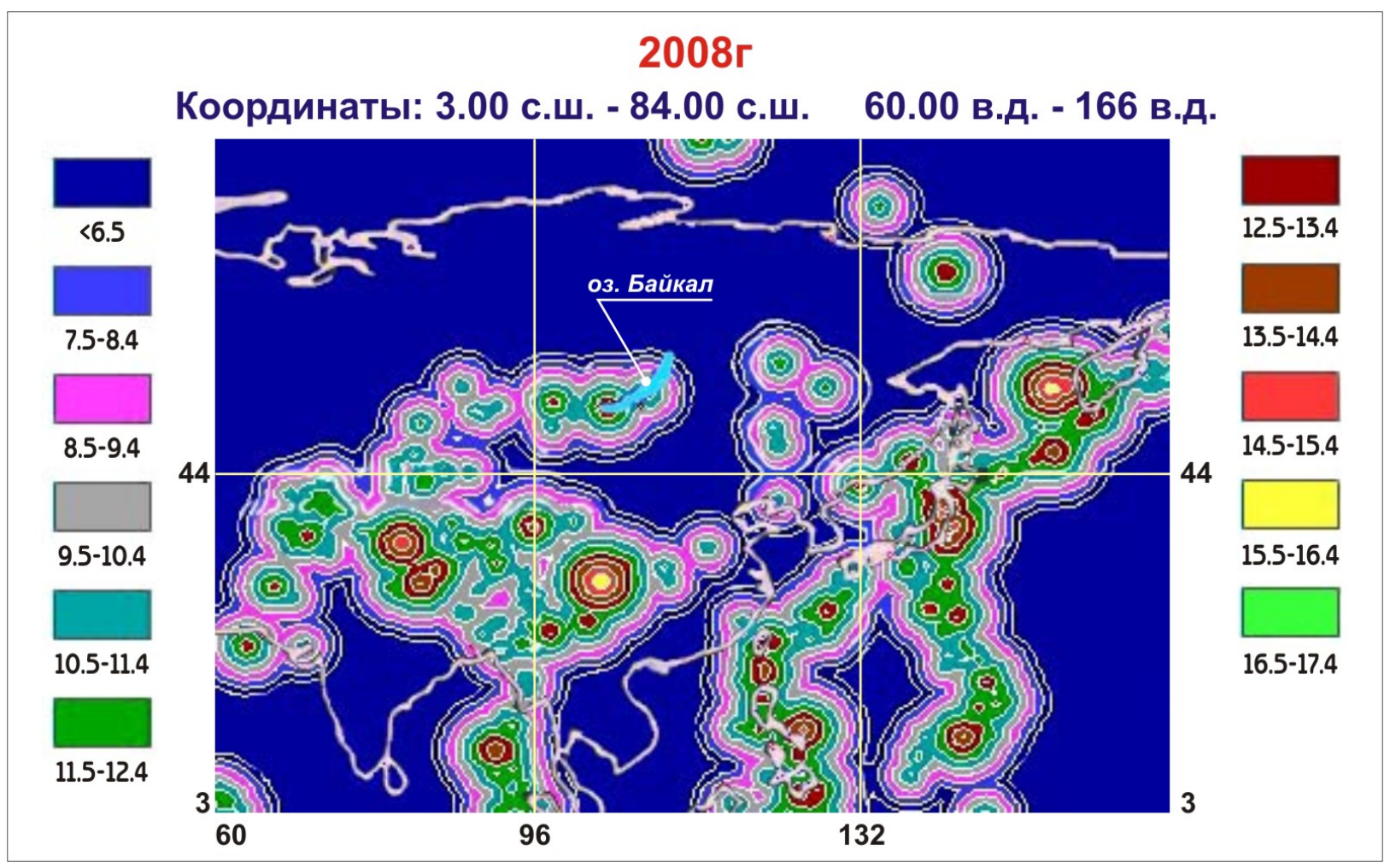

Рис. 9. Сейсмическая энергия, выделившаяся в 2008 г. в Индо-Евразийской коллизионной зоне и в западном сегменте Тихоокеанского сейсмического кольца и распространившаяся в глубь Центральной Азии. В изолиниях показано количество сейсмической энергии в значениях энергетических классов, нормированное на единицу площади (см. условные обозначения). Фронт распространения сейсмической энергии в периоды сейсмической активизации на границах плит может достигать области Байкальского рифта и таким образом инициировать прибайкальские землетрясения (например, Култукское землетрясение 27.08.2008 г., M=6.3).

Fig. 9. Propagation of seismic energy, released in the Indo-Eurasian collision zone and in the western segment of the Pacific seismic ring, into Central Asia in 2008. Isolines show quantities of seismic energy in values of power classes normalized to an area unit (see Legend). During seismic reactivation at plate boundaries, the seismic energy propagation front can reach the Baikal rift area and thus initiate earthquakes in this area (an example is the Kultuk earthquake of $M=6.3$ which occurred on 27 August 2008).

мальной тектонической активности в позднем плиоцене, когда вулканотектонические структуры были переработаны неотектоническими структурами. В почти нетронутом виде сохранились две подобные структуры - кольцевые впадины Окинского плоскогорья и Тоджинской котловины.

В 1996 г. К.Г. Леви и Н.В. Задониной начато изучение современной геодинамики в рамках исторических хронологий Сибири, а затем в истории мировой цивилизации. В настоящее время в завершающей стадии находятся работы по созданию и интерпретации радиоуглеродных хронологий комплекса природных процессов в Северном полушарии [Задонина, Леви, 2008, 2009; Задонина и др., 2007]. Это первый опыт подобных исследований по созданию базы данных, объем которой достигает 40000 дат. Полученные в этой работе статистические закономерности развития природных процессов в рамках концепции глобальных природно-климатических изменений представляют собой некую первичную стандартную модель эволюции природной среды за прошедшие 50000 лет с выявлением природных отклонений регионального плана.

С применением ГИС-технологий детально проанализированы параметры миграции эпицентраль- ных полей землетрясений, которые характеризуют фризические пульсационные механизмы распространения периодически активизируемых фронтов сейсмотектонических деформаций из области коллизии в глубь Центрально-Азиатского сегмента Евразийской плиты с достижением сегментов Байкальской рифттовой зоны (рис. 9).

\section{ГЕОФИЗИЧЕСКИЕ ИССЛЕДОВАНИЯ В ЦЕНТРАЛЬНОЙ АЗИИ}

Аномально низкие скорости были установлены в мантии под Байкальской рифтовой зоной уже в 1970-х годах [Рогожина, Кожевников, 1979]. Скоростная глубинная структура мантии изучалась по 27 сейсмическим станциям, выставленным вдоль профиля от Сибирской платформы через Байкал в Монголию в рамках российско-американского проекта в 1991 г. Полученные результаты подтвердили поднятие границы литосферы-астеносферы под рифтовой зоной и ее асимметричную форму [Gao et al., 1994].

Новым важным результатом явилась трехмерная сейсмическая модель S-волн, построенная для верхней мантии Азии по записям широкополосных цифровых станций IRIS с дополнительными дан- 

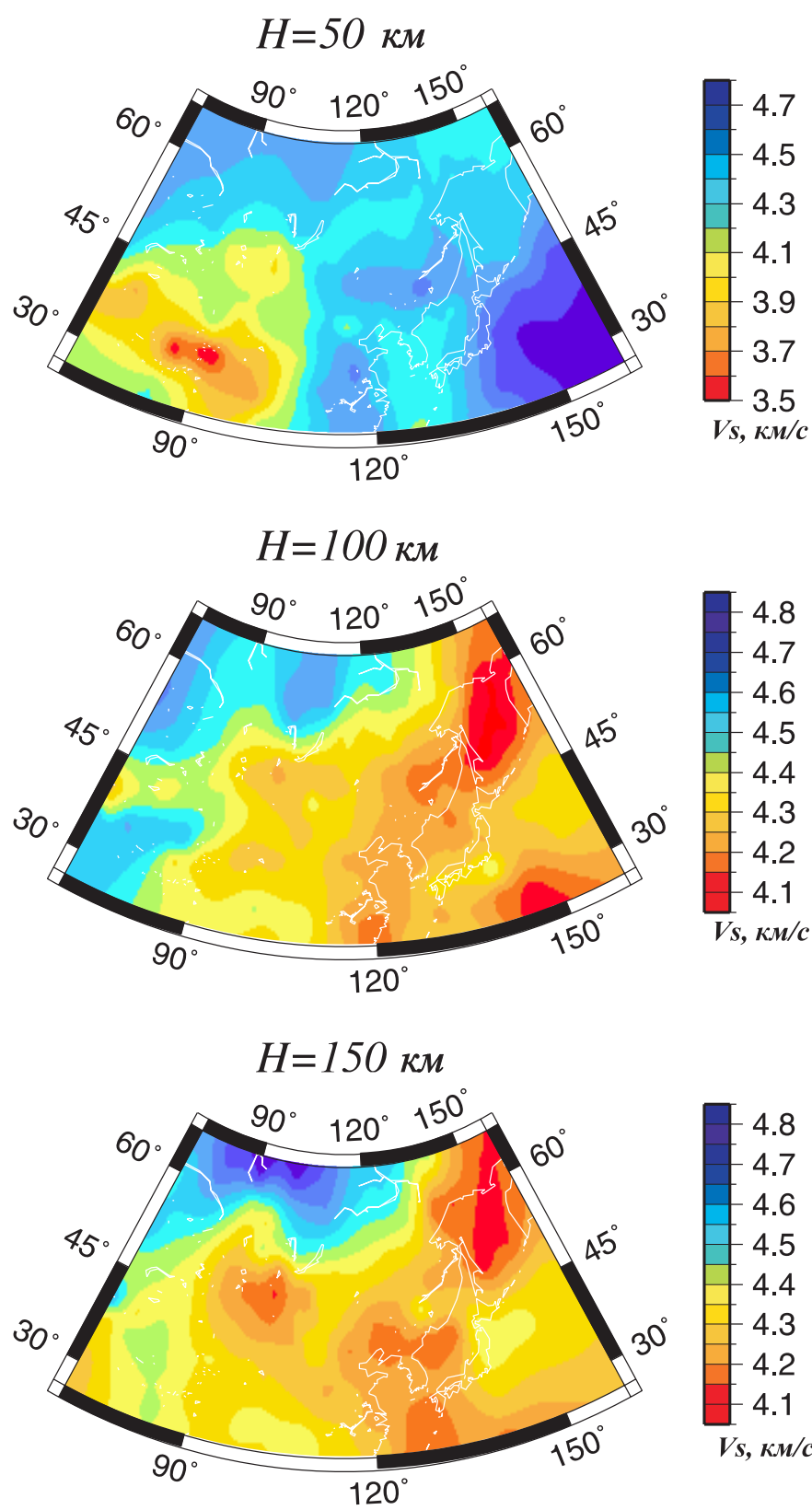

$V_{S}, \kappa M / c$

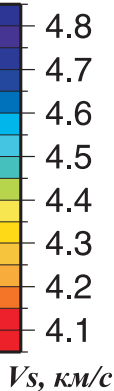

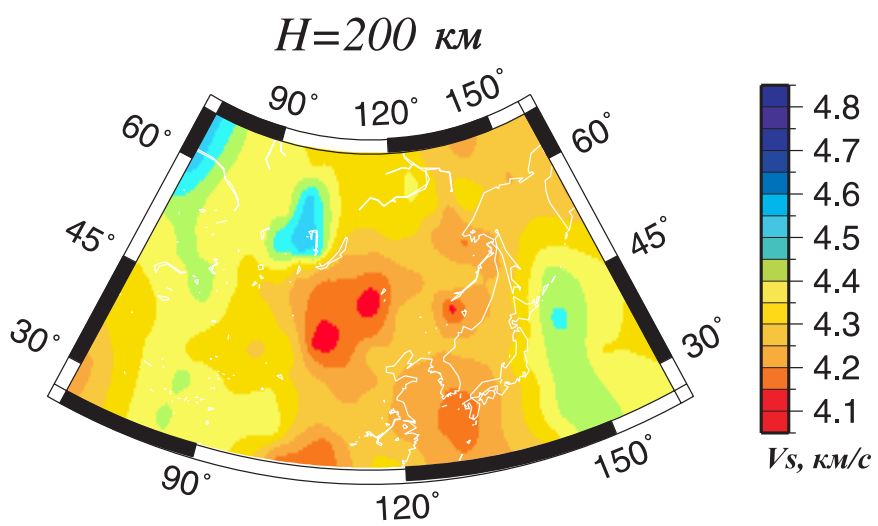
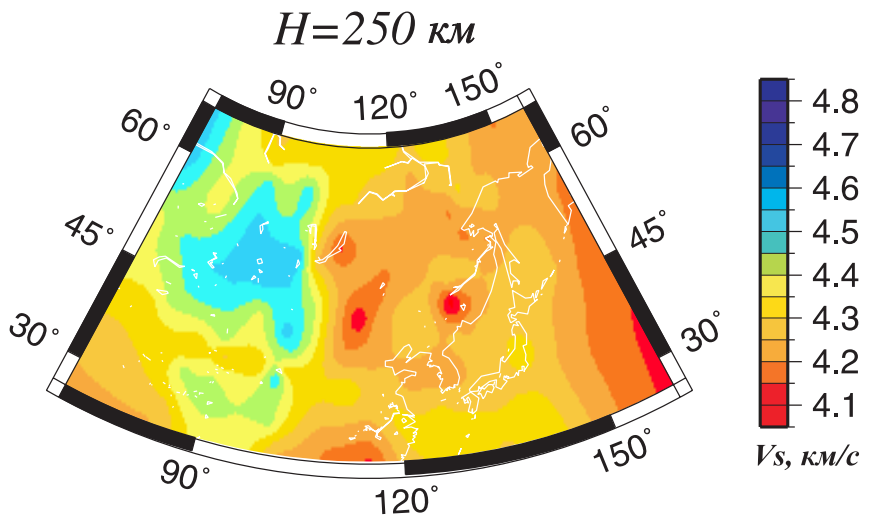

$V S, \kappa M / c$
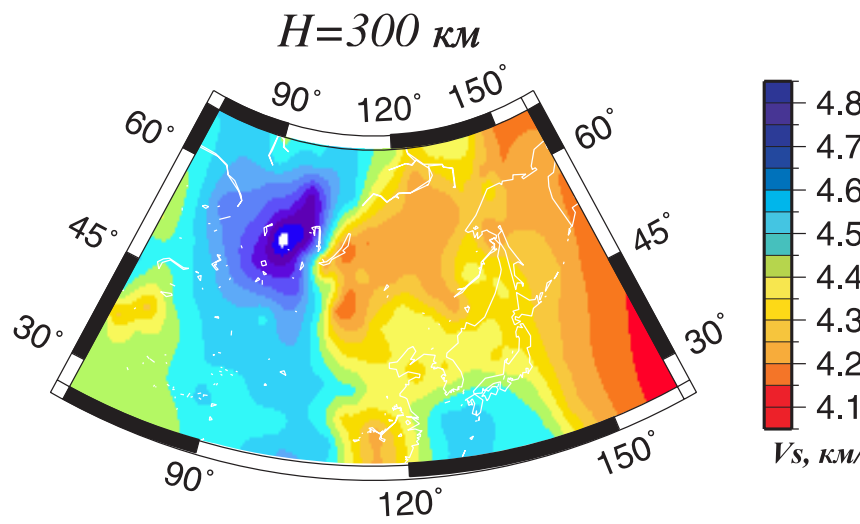

VS, $\kappa M / c$

Рис. 10. Распределение скоростей S-волн в верхней мантии Азии [Yanovskaya, Kozhevnikov, 2003].

Fig. 10. Distribution of S-wave velocities in the upper mantle of Asia [Yanovskaya, Kozhevnikov, 2003].

ными временных цифровых станций, использованных в 1991-1992 гг. в работах по российско-американскому проекту «Телесейсмическая томография Байкальского рифта», и оцифрованным аналоговым записям сейсмических станций Новосибирска, Иркутска и Южно-Сахалинска в период 19751987 гг. [Yanovskaya, Kozhevnikov, 2003] (рис. 10). Определен главный мотив кайнозойской глубинной динамики Азии, вытекающий из связи эволюции магматизма Центрально-Азиатской орогенной системы с мантийными процессами в Саяно-Монгольском низкоскоростном домене (интервал глубин 50-200 км) и магматизма восточной окраины Азии с процессами в Забайкальском низкоскоростном до- мене (интервал глубин 200-350 км) (рис. 11).

\section{ЗАКЛЮЧЕНИЕ}

Фундаментальные представления о строении и развитии Байкальской системы рифтовых впадин были заложены в трудах Н.А. Флоренсова и Н.А. Логачева. Высокая степень изученности кайнозойских континентальных рифртовых зон Евразии, Африки и Северной Америки, а также новые методики и возможности обработки и анализа больших массивов геологической и геофизической информации выдвинули на рубеже XX и XXI столетий в качестве приоритетной задачи создание комплексной 

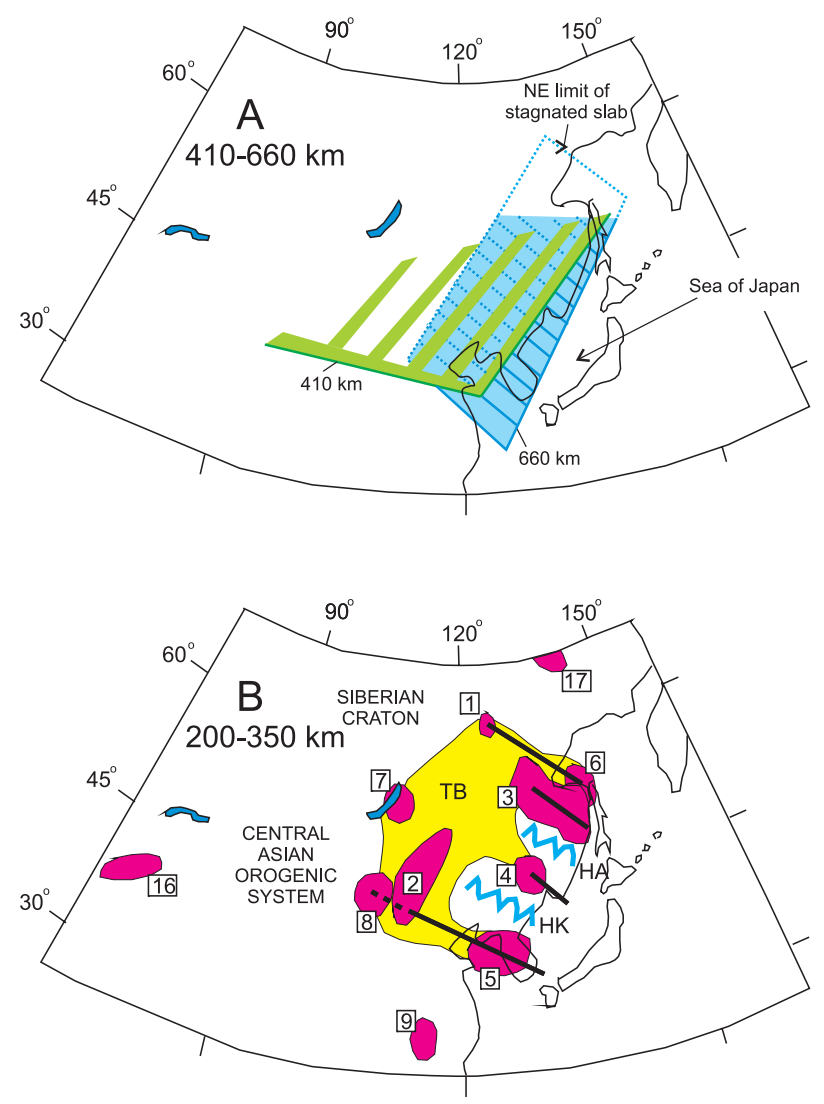

\section{LEGEND} slab at the 660-km discontinuity

Block with high reflectivity of the $410-\mathrm{km}$ discontinuity

Low-velocity domain

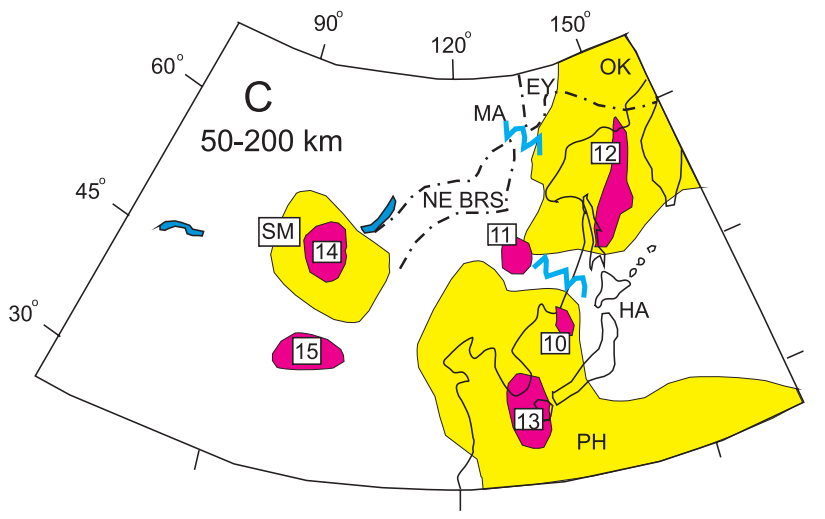

Local lowvelocity anomaly Locus of northwestward trending local low-velocity anomalies

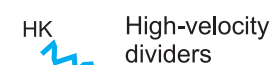
dividers

1 between low-velocity anomalies zone

Рис. 11. Высокоскоростные аномалии на разделах 660 и 440 км, имеющие слэбовое происхождение, (A) и пространственные соотношения следов горячих пятен кайнозойского вулканизма с низкоскоростными аномалиями Центральной и Восточной Азии глубинных ярусов 200-350 км (B) и 50-200 км (C) [Рассказов и др., 2003а; Rasskazov et al., 2004]. Низкоскоростные домены: более глубинный (250-350 км) Забайкальский (TB) и менее глубинные (150 км) Саяно-Монгольский (SM), Филиппиноморский (РН), Охотоморский (ОК). Низкоскоростные локальные аномалии (цифры в прямоугольниках): Ленская (1, глубина 300-350 км) и Восточно-Монгольская (2, глубина 250 км), Совгаванско-Удская (3, глубина 200-250 км), Амурская (4, глубина 200-250 км), Северо-Корейская (5, глубина 200-250 км), Северо-Сахалинская (6, глубина 300 км), Южно-Приморская (10, глубина 100 км), Южно-Корейская (13, глубина 200 км), СевероБайкальская (7, глубина 250 км), Южно-Монгольская (8, глубина 200 км), Южно-Китайская (9, глубина 300-350 км), Таримская (16, глубина 300-350 км), Хелунцзянская (11, глубина 100 км), Северо-Монгольская (14, глубина 150 км), Цайдамская (15, глубина 100 км), Эльгинская (17, глубина 200 км), Сахалино-Магаданский аномальный выступ над Охотоморским доменом (12, глубина 100 км). Высокоскоростные перемычки между низкоскоростными аномалиями: НА - Хоккайдо-Амурская, НН - Хонсю-Хинганская. Малоглубинные (50 км) низкоскоростные зоны северо-восточной части Байкальской рифтовой системы (NE BRS) и структур Восточной Якутии (ЕY) [Рассказов и др., 2003а]. Схема составлена на основе скоростной модели S-волн [Yanovskaya, Kozhevnikov, 2003; Aкmyальные вопросы..., 2005], показанной на рис. 10.

Fig. 11. Slab-related high-velocity anomalies at $660-\mathrm{km}$ and $440-\mathrm{km}$ discontinuities (A) and low velocity anomalies within mantle stages of 200 $350 \mathrm{~km}(A)$ and 50-200 km (B) in East and Central Asia [Рассказов и дp., 2003a; Rasskazov et al., 2004]. Low velocity domains: TB - Transbaikal, SM - Sayan-Mongolia, OS - Okhotsk sea, PH - Philippine sea. Local low velocity anomalies: 1 - Lena (depth $300-350 \mathrm{~km}), 2$ - East Mongolia (250 km), 3 - Sovgavan-Uda (200-250 km), 4 - Amur (200-250 km), 5 - North Korea (200-250 km), 6 - North Sakhalin (300 km), 7 - North Baikal $(250 \mathrm{~km}), 8$ - South Mongolia (200 km), 9 - South China (300-350 km), 10 - South Primorye (100 km), 11 - Heilongjiang (100 km), 12 - Sakhalin-Magadan (above the Okhotsk sea domain), 13 - South Korea (200 km), 14 - North Mongolia (150 km), 15 - Tsaidam (100 km), 16 - Tarim (300-350 km), 17 - Elga (200 km). High-velocity dividers: HA - Hokkaido-Amur, HK - Honshu-Khingan. Shallow low velocity zones: NE BRS - Northeastern Baikal rift system, EY - East Yakutia [Рассказов и дp., 2003a]. The scheme is compiled on basis of the tomographic model of S-waves by Yanovskaya and Kozhevnikov [2003], shown in Fig. 10. 
модели развития рифтогенеза с его зарождения до современности. Решение поставленной задачи осуществлялось в рамках работ научной школы «Кайнозойский континентальный рифтогенез» под руководством Н.А. Логачева (РФФИ 00-15-98574). В ней было выделено пять основных направлений: 1) изучение вулканогенных и осадочных формаций Байкальской и Восточно-Африканской рифтовых систем, 2) тектонофизические исследования развития Байкальской рифтовой зоны на Байкальском и Монгольском геодинамических полигонах, 3) выявление современных движений земной коры методами GPS-геодезии, 4) геологические исследования и 5) геофизическое изучение Прибайкалья и Забайкалья.

Полученные результаты позволяют аргументированно объяснять значительное влияние коллизионных процессов Альпийско-Гималайской зоны на внутриплитные рифтогенные процессы, зарождение и развитие которых связано с местными мантийными процессами. В настоящее время находят подтверждение и развитие многие идеи академика Н.А. Логачева, в том числе о комбинированном механизме возникновения и геолого-структурного развития элементов Байкальской рифтовой зоны.

Статья включает обзор материалов по проекту НИР в рамках реализации ФЦП «Научные и научнопедагогические кадры инновационной России» на 2009-2013 годы, государственный контракт П763 от 20.05.2010.

\section{ЛИТЕРАТУРА}

Актуальные вопросы современной геодинамики Центральной Азии / Отв. ред. К.Г. Леви, С.И. Шерман. - Новосибирск: Издво СО РAH, 2005. - 297 с

Белоусов В.В., Герасимовский В.И., Горячев А.В., Добровольский В.В., Капица А.П., Логачев Н.А., Милановский Е.Е., Поляков А.И., Рыкунов Л.Н., Седов В.В. Восточно-Африканская рифтовая система. Т. І. Основные черты строения. Стратиграфия. - М.: Наука, 1974а. - 264 с.

Белоусов В.В., Герасимовский В.И., Горячев А.В., Добровольский В.В., Капица А.П., Логачев Н.А., Милановский Е.Е., Поляков А.И., Рыкунов Л.Н., Седов В.В. Восточно-Африканская рифтовая система. Т. II. Гипергенные образования. Геоморфология. Неотектоника. - М.: Наука, 1974б. - 264 с.

Белоусов В.В., Герасимовский В.И., Горячев А.В., Добровольский В.В., Капица А.П., Логачев Н.А., Милановский Е.Е., Поляков А.И., Рыкунов Л.Н., Седов В.В. Восточно-Африканская рифтовая система. Т. ІІ. Геохимия. Сейсмология. Основные результаты. - М.: Наука, 1974в. - 288 с.

Задонина Н.В., Леви К.Г. Хронология природных и социальных феноменов в Сибири и Монголии. - Иркутск: Изд-во ИГУ, 2008. $-759 \mathrm{c}$

Задонина Н.В., Леви К.Г. Хронология природных и социальных феноменов в истории мировой цивилизации. - Иркутск: Издво ИГУ, 2009. - 864 с

Задонина Н.В., Леви К.Г., Язев С.А. Космические опасности геологического и исторического прошлого Земли. - Иркутск: ИЗК CO PAH, 2007. - 77 c.

Карта современной геодинамики Азии / К.Г. Леви, С.И. Шерман, В.А. Саньков и др. - Иркутск: ИЗК СО РАН, 2007

Леви К.Г. Карта неотектоники северо-восточного сектора Азии. Иркутск: ГП «475 Военно-топографическая фабрика», 2008.

Леви К.Г., Бабушкин С.М., Бадардинов А.А. и др. Активная тектоника Байкальской впадины // Геология и геофизика. - 1995. T. 36, № 10. - С. 154-163

Логачев Н.А. Вулканогенные и осадочные формации рифтовых зон Восточной Африки. - М.: Наука, 1977. - 183 с.

Логачев Н.А. История и геодинамика Байкальского рифта // Гео- логия и геофизика. - 2003. - Т. 44, № 5. - С. 391-406.

Логачев Н.А., Борняков С.А., Шерман С.И. О механизме формирования Байкальской рифтовой зоны по результатам физического моделирования // Доклады АН. - 2000. - Т. 373, № 3. - С. 388-390.

Логачев Н.А., Брандт И.С., Рассказов С.В., Иванов А.В., Брандт С.Б., Конев А.А., Ильясова А.М. Определение K-Ar возраста палеоценовой коры выветривания Прибайкалья // Доклады АН. - 2002. - Т. 385, № 6. - С. 797-799.

Логачев Н.А., Рассказов С.В., Иванов А.В., Мишарина В.А., Черняева Г.П. Стратиграфия верхнекайнозойской вулканогенноосадочной толщи прибайкальской части Восточного Саяна // Стратиграфия. Геологическая корреляция. - 1998. - Т. 6, № 4. - C. 81-91.

Логачев Н.А., Шерман С.И., Леви К.Г. Геодинамическая активность литосферы, ее интегральная оценка и связь с сейсмичностью // Современная тектоническая активность Земли и сейсмичность. - М.: Наука, 1987а. - С. 97-108

Логачев Н.А., Шерман С.И., Леви К.Г. Геодинамическая активность литосферы Сибири в кайнозое // Геология и геофизика. - 19876. - № 8. - С. 3-10.

Логачев Н.А., Шерман С.И., Леви К.Г., Трифонов В.Г. Геодинамическая активность литосферы Азии: основы анализа и принципы картирования // Геодинамика и развитие тектоносферы: Труды тектонического совещания МТК. - М.: Наука, 1991. - С. 31-39.

Лухнев А.В., Саньков В.А., Мирошниченко А.И., Леви К.Г., Башкуев Ю.Б., Дембелов М.Г., Залуцкий В.Т., Кале Э., Девершер Ж., Верноль М., Бехтур Б., Амаржаргал Ш. Новые данные о современных тектонических деформациях южного горного обрамления Сибирской платформы // Доклады АН. - 2003. T. 389, № 1. - С.100-103.

Милановский Е.Е. Рифтовые зоны континентов. - М.: Недра, 1976. $-279 \mathrm{c}$

Николай Александрович Флоренсов / Отв. ред. Н.А. Логачев. Новосибирск: Изд-во СО РАН, 2003. - 171 с.

Рассказов С.В. Магматизм Байкальской рифртовой системы. - Новосибирск: ВО "Наука". Сибирская издательская фирма, 1993. $288 \mathrm{c}$.

Рассказов С.В., Логачев Н.А., Брандт И.С., Брандт С.Б., Иванов A.B. Геохронология и геодинамика позднего кайнозоя (Южная Сибирь - Южная и Восточная Азия). - Новосибирск: Наука, 2000. $-288 \mathrm{c}$

Рассказов C.B., Логачев Н.A. Иванов А.В. Корреляция позднекайнозойских тектонических и магматических событий Байкальской рифтовой системы с событиями на юго-востоке Евразиатской плиты // Геотектоника. - 1998. - № 4. - С. 25-40.

Рассказов С.В., Логачев Н.А., Иванов А.В., Бовен А.А., Масловская М.H., Саранина Е.В., Брандт И.С., Брандт С.Б. Магматический эпизод Западного рифта Восточной Африки 19-17 млн лет назад // Геология и геофизика. - 2003a. - Т. 44, № 4. - C. 317-324.

Рассказов С.В., Логачев Н.А., Иванов А.В., Мишарина В.А., Черняева Г.П., Брандт И.С., Брандт С.Б., Скобло В.М., Лямина Н.A. Палинологический и диатомовый анализ осадков из позднекайнозойской долины пра-Амалата (Западное Забайкалье) // Геология и геофизика. - 2001. - Т. 42, № 5. - С. 773785.

Рассказов С.В., Логачев Н.А., Кожевников В.М., Яновская Т.Б. Ярусная динамика верхней мантии Восточной Азии: соотношения мигрирующего вулканизма и низкоскоростных аномалий // Доклады АН. - 2003б. - Т. 390, № 1. - С. 90-95.

Рогожина В.А., Кожевников В.М. Область аномальной мантии под Байкальским рифтом. - Новосибирск: Наука. Сиб. отдние, 1979. - 104 с

Ружич В.В. Влияние древних разрывов на развитие новейших структур Байкальского рифта // Геология и геофизика. - 1975 - № 1. - C. $130-136$.

Ружич В.В. О сочетании напряжений растяжения и сжатия в Байкальском рифте // Тектоника и сейсмичность континентальных рифтовых зон. - М.: Наука, 1978. - С. 27-32.

Ружич B.В. Сейсмотектоническая деструкция в земной коре Байкальской рифтовой зоны. - Новосибирск: Изд-во СО РАН, 1997. - $144 \mathrm{c}$

Ружич В.В., Псахье С.Г., Черных Е.Н., Борняков С.А., Гранин Н.Г. Деформации и сейсмические явления в ледяном покрове озера Байкал // Геология и геофизика. - 2009. - Т. 50, № 3. C. 289-299.

Ружич В.В., Трусков В.А., Черных Е.Н., Смекалин О.П. Совре- 
менные движения в зонах разломов Прибайкалья и механизмы их инициирования // Геология и геофизика. - 1999. - Т. 40, № 3. - С. 360-372.

Ружич В.В., Шерман С.И., Тарасевич С.И. Новые данные о надвигах в юго-западном фланге Байкальской рифтовой зоны // Доклады АН СССР. - 1972. - Т. 205, № 4. - С. 920-924.

Саньков В.А., Лухнев А.В., Мирошниченко А.И., Леви К.Г., Ашурков С.В., Башкуев Ю.Б., Дембелов М.Г., Кале Э., Девершер Ж., Верноль М., Бехтур Б., Амаржаргал Ш. Современные движения земной коры Монголо-Сибирского региона по данным GPS-геодезии // Доклады АН. - 2003. - Т. 392, № 6. - С. 792-795.

Флоренсов Н.А. Мезозойские и кайнозойские впадины Прибайкалья. - М.-Л.: Изд-во Академии наук СССР, 1960. - 258 с.

Шенгёр А.М.С., Натальин Б.А. Рифты мира. Учебно-справочное пособие. Пер. с англ. - М.: Геокарт, 2009. - 188 с.

Шерман С.И. Физические закономерности формирования разломов в земной коре. - Новосибирск: Наука. Сиб. отд-ние, 1977. $-102 \mathrm{c}$.

Шерман С.И. Тектонофизическая модель сейсмической зоны: опыт разработки на примере Байкальской рифтовой системы // Физика Земли. - 2009. - № 11. - С. 8-21.

Шерман С.И., Леви К.Г. Трансформные разломы Байкальской рифтовой зоны // Доклады АН СССР. - 1977. - Т. 233, № 2. C. $461-464$

Шерман С.И., Медведев М.Е., Ружич В.В., Киселев А.И., Шмотов А.П. Тектоника и вулканизм юго-западной части Байкальской рифтовой зоны. - Новосибирск: Наука. Сиб. отд-ние, 1973. $136 \mathrm{c}$.

Шерман С.И., Семинский К.Ж., Борняков С.А., Буддо В.Ю., Лобацкая P.М., Адамович А.Н., Трусков В.А., Бабичев А.А. Разломообразование в литосфере. Зоны сдвига. - Новосибирск: Наука, 1991. - 261 с

Шерман С.И., Семинский К.Ж., Борняков С.А., Адамович А.Н. Лобацкая Р.М., Лысак С.В., Леви К.Г. Разломообразование в литосфрере. Зоны растяжения. - Новосибирск: Наука, 1992. $262 \mathrm{c}$.

Шерман С.И., Семинский К.Ж., Борняков С.А., Адамович А.Н., Буддо В.Ю. Разломообразование в литосфере. Зоны сжатия. - Новосибирск: Наука, 1994. - 263 с.

Calais E., Vergnolle M., San'kov V., Lukhnev A., Miroshnichenko A., Amarjargal S., Dévershèr J. GPS measurements of crustal deformation in the Baikal-Mongolia area (1994-2002): implications for current kinematics of Asia // Journal of Geophysical Research. - 2003. - V. 108, № B10. - 2501. - doi: 10.1029/2002JB002373 2003.

Gao S., Davis P.M., Liu H., Slack PD., Zorin Y.A., Logatchev N.A., Kogan M., Burkholder P.D., Meyer R.P. Asymmetric upwarp of the asthenosphere beneath the Baikal rift zone, Siberia // Journal of Geophysical Research. - 1994. - V. 99, № B8. - P. 1531915330.

Gregory J.W. Contributions to the physical geography of British East
Africa // The Geographical Journal. - 1894. - V. 4. - P. 290-315, 408-424, 505-514.

Kashik S.A., Mazilov V.N. Main stages and paleogeography of Cenozoic sedimentation in the Baikal rift system (Eastern Siberia) // Bull. Centres Rech. Explor.-Prod. Elf. Aquitaine. - 1994. - V. 18, № 2. - P. 453-461.

Klerkx J., Logatchev N.A., Ermikov V.D., Levi K.G. The CASIMIR project: a joint research project on rift basin geology between $\mathrm{Si}$ beria and Belgium // Science policy: New mechanisms for scientific collaboration between East and West / V. Koptyug and J. Klerkx (eds). NATO ASI Series. - Kluver Academic Press, 1995. - P. 117-125.

Levi K.G., Miroshnitchenko A.I., Sankov V.A., Babushkin S.M., Larkin G.V., Badardinov A.A., Wong H.K., Colman S., Delvaux D. Active faults of the Baikal depression // Bull. Centres Rech. Explor.Prod. Elf. Aquitaine. - 1997. - V. 21, № 2. - P. 399-434.

Logatchev N.A. History and geodynamics of the lake Baikal rift in the context of the Eastern Siberia rift system: a review // Bull. Centres Rech. Explor. Prod. Elf. Aquitaine. - 1993. - V. 17, № 2. - P. 353-370.

Logatchev N.A., Florensov N.A. The Baikal system of rift valleys // Tectonophysics. - 1978. - V. 45, № 1-2. - P. 1-15.

Logatchev N.A., Rasskazov S.V., Ivanov A.V. Late Cenozoic tectonic and volcanic episodisity in the Baikal rift system: Comparisons with southern and eastern margins of the Eurasian plate // 30th International Geological Congress Abstracts. V. 1. - Beijing, China, 1996. - P. 245.

Logatchev N.A., Zorin Yu.A. Evidence and causes of the two stage development of the Baikal rift // Tectonophysics. - 1987. - V 143, № 1-3. - P. 225-234.

Logatchev N.A., Zorin Yu.A. Baikal rift zone: structure and geodynamics // Tectonophysics. - 1992. - V. 208. - P. 273-286.

Logatchev N.A., Zorin Yu. A., Rogozhina V.A. Baikal rift: Active or passive? - Comparison of the Baikal and Kenya rift zones // Tectonophysics. - 1983. - V. 94, № 1-4. - P. 223-240.

Rasskazov S.V. Magmatism related to the East Siberia rift system and the geodynamics // Bull. Centres Rech. Explor.-Prod. Elf. Aquitaine. - 1994. - V. 18, № 2. - P. 437-452.

Rasskazov S.V., Brandt S.B., Brandt I.S. Radiogenic isotopes in geologic processes. - Dordrecht, Heidelberg, London, New York: Springer, 2010. - $306 \mathrm{p}$.

Rasskazov S., Taniguchi H., Goto A., Litasov K. Magmatic expression of plate subduction beneath East Asia in the Mesozoic through Cenozoic // Northeast Asian Studies. - 2004. - V. 9. - P. 179-219.

Yanovskaya T.B., Kozhevnikov V.M. 3D S-wave velocity pattern in the upper mantle beneath the continent of Asia from Rayleigh wave data // Physics of the Earth and Planetary Interiors. - 2003. - V. 138. - P. 263-278.

Zamarayev S.M., Ruzhich V.V. On relationships between the Baikal rift and ancient structures // Tectonophysics. - 1978. - V. 45, № 1. - P. 41-47.

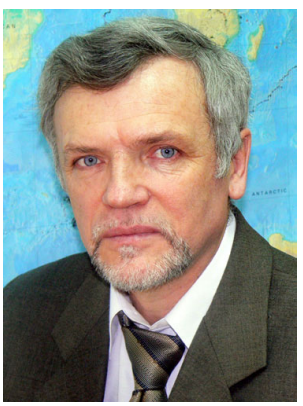

Рассказов Сергей Васильевич, докт. геол.-мин. наук, профессор, зав. лабораторией Институт земной коры СО РАН

664033, Иркутск, ул. Лермонтова, 128, Россия

Тел. (3952)511659; e-mail: rassk@crust.irk.ru

Rasskazov Sergey V., Doctor of Geology and Mineralogy, Head of Laboratory

Institute of the Earth's Crust, Siberian Branch of RAS

664033, Irkutsk, Lermontov street, 128, Russia

Tel. +7(3952)511659; e-mail: rassk@crust.irk.ru 

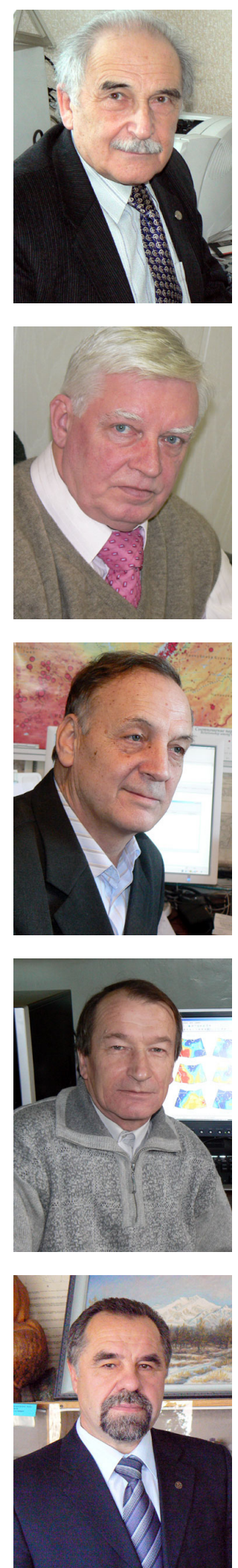

Шерман Семен Иойнович, академик Российской академии естественных наук, докт. геол.-мин. наук, профессор, г.н.с.

Институт земной коры СО РАН

664033, Иркутск, ул. Лермонтова, 128, Россия

тел.: (3952)428261, e-mail: ssherman@crust.irk.ru

Sherman Semen I., Academician of the Russian Academy of Natural Sciences,

Doctor of Geology and Mineralogy, Professor, Chief Researcher

Institute of the Earth's Crust, Siberian Branch of RAS

664033, Irkutsk, Lermontov street, 128, Russia

Tel. +7(3952)428261, e-mail: ssherman@crust.irk.ru

Леви Кирилл Георгиевич, докт. геол.-мин. наук, профессор,

зам. директора института по науке

Институт земной коры СО РАН

664033, Иркутск, ул. Лермонтова, 128, Россия

Тел. (3952)424562; e-mail: levi@crust.irk.ru

Levi Kirill G., Doctor of Geology and Mineralogy, Professor, Deputy Director

Institute of the Earth's Crust, Siberian Branch of RAS

664033, Irkutsk, Lermontov street, 128, Russia

Tel. +7(3952)424562; e-mail: levi@crust.irk.ru

Ружич Валерий Васильевич, докт. геол.-мин. наук, г.н.С.

Институт земной коры СО РАН

664033, Иркутск, ул. Лермонтова, 128, Россия

Тел. (3952)422776; e-mail: ruzhich@crust.irk.ru

Ruzhich Valery V., Doctor of Geology and Mineralogy, Chief Researcher

Institute of the Earth's Crust, Siberian Branch of RAS

664033, Irkutsk, Lermontov street, 128, Russia

Tel. +7(3952)422776; e-mail: ruzhich@crust.irk.ru

Кожевников Владимир Михайлович, канд. физ.-мат. наук, с.н.с

Институт земной коры СО РАН

664033, Иркутск, ул. Лермонтова, 128, Россия

Тел. (3952)424680; e-mail: kozh@crust.irk.ru

Kozhevnikov Vladimir M., Candidate of Physics and Mathematics, Senior Researcher Institute of the Earth's Crust, Siberian Branch of RAS

664033, Irkutsk, Lermontov street, 128, Russia

Тел. +7(3952)424680; e-mail: kozh@crust.irk.ru

Саньков Владимир Анатольевич, канд. геол.-мин. наук, зав. лабораторией Институт земной коры СО РАН

664033, Иркутск, ул. Лермонтова, 128, Россия

Тел. (3952)427903; e-mail: sankov@crust.irk.ru

San'kov Vladimir A., Candidate of Geology and Mineralogy, Head of Laboratory Institute of the Earth's Crust, Siberian Branch of RAS

664033, Irkutsk, Lermontov street, 128, Russia

Tel. +7(3952)427903; e-mail: sankov@crust.irk.ru 